HAYKUHI GEVORGYAN

Director of Methodological Center

for Professional Orientation

\title{
PROFESSIONAL ORIENTATION AS LIFELONG PROCESS
}

What profession to choose? The question is inevitable; the answer is seeking every individual in some stage of his age or social development. The solution of the issue is very importance not only for his personality but generally for society. Professional orientation helps the youth for professional consciousness. Professional orientation is normal continuation of educational work and is considered to be its logical end in some respects. Providing consultancy to individual for professional orientation aims not only assisting to organize his learning process, but assuring confidence towards his future from psychological point of view.

Platon wrote in his era: "Every individual should have such occupation that the state needs and in which he is most suitable with all his nature. Thus about 2.5 thousand years ago Platon outlined the separation of individuals' activity roles in the development of work and society.

Professional orientation is a function; the aim is to provide comprehensive information on labor market current condition and development trends, opportunities offered by educational system, professions, personal qualities and inclinations allowing him to make a conscious and rational decision.

Different theorists are describing professional orientation services and implementation methods differently. However it should be stated that the principles are united. Therefore using this or that theory, maintaining the sequence of service delivery methods is not compulsory condition. Professional orientation implementation principles are arranged by the individual's needs. Concrete method use for professional orientation implementation results these needs. Need to mention that each method has its own work principles. Below are the basic methods

1. Professional awareness: it covers dissemination of the information on professions and occupations world, opportunities and conditions for education and training

2. Professional research is the study of the individual for delivering professional orientation services. The characteristics of individual's temperament, needs, value orientation, interests, abilities, initial professional preference are studied in this process.

3. Professional consultancy aims to identify personal characteristics of the individual and correspondence of this or that occupation/profession demand. Consultancy can be conducted by group or individual form, if they are preparation or basic stages, but the final stage should be conducted by personal talk, it is possible with the participation of parents. Professional consultancy can be of information and pshyco-pedagogical nature. As a result, the teenager or young person must get comprehensive response on the profession he is interested in, the opportunities of getting education and training with this profession. As ensuring the effectiveness of this method, other methods will be necessary to apply to continue the work: visits to different workplaces, meetings with students and lecturers of various vocational educational institutions, participation in events, meetings and other measures organized for professional orientation. The individual should be given professional consultancy conclusion in this phase. 
4. Professional choice method aims to identify human adaptation towards specific work, occupation. These activities, as a rule, are implemented out of school in special laboratories or enterprises, in the employer, where are special facilities according to professions.

It is necessary to distinguish the selection of a profession from the selection of the professions. It seems they are identical, but differ from each other in methodology. While choosing the profession, most suitable individual for this profession is chosen and while choosing the professions it refers to selection of the profession in line with individual's personal peculiarities, namely the method supposes transition from individual to profession

5. In social-professional stage young person's adaptation to new social environment, work conditions and concrete professions is realized through active processes. Stage of professional adaptation success is one of main criteria of profession's right choice, evaluation of professional orientation works' efficiency

6. Professional education aims to form responsibility, sense of commitment, independent decision making, capacity to make a choice

While referring to professional self determination concept as professional orientation works result, the connection between the main components of professional self determination is necessary to understand. This topic is considered to be a separate subject of numerous investigations.

A number of researchers believe that one of the main components of professional self determination is the development of individual's interest in different areas of professional activity. Interest towards profession in individual's professional self determination process takes priority. There are numerous phycho-pedagogical methods for interest disclosure.
Needs and interests are considered to be main conditions for individual's further value orientation. Planning his future and identifying concrete measures, goals and actions the individual first proceeds from certainly classified values, deep-rooted in his consciousness. Guiding in wide area of social values the individual makes choice closest to his needs.

The values, in turn, put forth the motives. Values passing through individual lifestyle, intrude to individual's mental world becoming individual values, which are considered to be one of the sources of activity motivation. Disclosure of profession choosing reasons allows finding out what especially motivated the individual to choose this occupation. This makes it possible to identify the person's attitude towards values.

The motive leads to action and the goal directs it.

Thus, own needs understanding is made, the sequence is being classified, preferences are being separated, interests are coming forth, which can be transformed into inclinations during their development, values are being formed, motives are being arranged, goals are clarified, those opportunities of the individual, which can enhance or hinder for achieving the goal are studied. After all these, concrete steps are determined to make, namely selfdetermination is taking place.

Professional orientation should be directly connected with its value orientation, which equally covers both social and public values. Each individual seeks to portray the values, which are mostly in line with his goals and interests. Relatively, the following values are the attributes of person's professional activity

$\checkmark$ Self affirmation in society, social environment

$\checkmark$ Authority in the workplace

$\checkmark$ Acquaintance by friends

$\checkmark$ Self improvement - interesting work

$\checkmark$ Use of knowledge and ability 
$\checkmark$ Creative approach towards work

$\checkmark$ Good remuneration: material and practical values

$\checkmark$ Position, career advancement opportunities, personal satisfaction

Thus, the individual's analysis is important precondition in professional orientation actions, according to which professional consultant should compile the characteristics of the person. It allows to provide more targeted and focused consultancy.

Use of professional orientation actions individual or group forms is expedient taking into account age groups. For example to separate elementary, primary and high school students for pupils, alumni and students should be considered as separate group. Or group them according to their needs, which are young people who need consultancy for profession choice, developing professional capacities and young people seeking for a job, etc. Monitoring, testing, interview and/ or conversation methods are useful to apply when necessary.

For example during observation the consultant must collect opinions about pupil or student from the teachers, friends studying the person in the environment surrounding him in order to file his final description. Monitoring results should be coordinated with the consultant's written description. The testing supposes non intermediate reveal of the individual's professional preferences and personal qualities. Testing different systems are being developed and operated for applying this method. The conversation must have thematic orientation, can be conducted with students, teachers, head teachers and school principals as well as with parents. Conversations can make experts, teachers, parents from variety areas. Conversation topics are professions, their characteristics, peculiarities of professional skills and capacity building. Alive communication can lead to more reliable result in this case, than testing.

Result of each meeting conducted with the individual is recorded and kept in his personal file in case of services supposing ongoing work.

Professional orientation goals are different in each group for school children:

In the elementary school - 1-4 grades - formation of profession ideas, understanding work roles in human lives through displaying variety of actions

First phase of basic school - 5-7 grades interests and capacity building with regard to professional choice

Second phase of basic school - 8-9 grades - formation of professional motivation by preparation of basic skills and inclinations' self analysis

High school - 10 - 12 grades - formation of self-determination value and conceptual sides, disclosure of pupils' professional planning and preferences, ability and capacity building through deep study of separate subjects in professional flows.

Parents' participation in children's profession selection is indisputable; works with parents is emphasized in professional orientation services. Experience shows that high school pupils face professional self determination problems when the individual is not formed as independent personality which is based mainly on family upbringing. In many cases parents with growing children are not fully aware of their problems. They are more inclined to make decisions instead of children, which is serious obstacle for individual's development process and hinders child's professional self determination. Choosing profession and finding ways to get education/training are hard issues both for children and their parents. Parents' psychological pressure attempts aimed at reduction of professional self determination process, as a rule, give negative result causing intolerance in children and sometimes rejection from any self determination step.

Parents' ideas about right choice of profession are staying beyond from real life 
and are more in line already with past step of country's socio-economic development. The reason is the emergence of new professions in labor market, new ways of economy's various branches. Children's interests and abilities are not always seen by parents from professional point of view and assessed objectively. Often their advices are based on this or that profession, the so called on authority. Especially parents of teenagers who are of Soviet mentality can hardly predict labor market demanded professions and values. Therefore the need arises for serious professional guidance with parents.

Services delivered to parents are also distinguished according to children's age and status. Separate goals and expected results are defined for each age group. The activities cover talks, discussions, acquaintance with labor market expected development, descriptions with various professions, also about professional educational system, learning opportunities and terms in the institutions conducting education and training.

Professional orientation process is not limited by school stages. It gets wider description in second phases of career planning and development: in college, learning period in University, after obtaining profession and qualification, seeking for job, implementing first job and/or on way to change the profession. To be short, it is lifelong process.

Individual's professional and civic society capacity building is more emphasized when working with the youth. Thus, the youth's professional orientation is aimed mainly to grace the individual with general capacities of career improvement for his ongoing development as a student, worker and citizen.

Career is sequence and diversity in person's work role during life. In wider sense it covers life roles, leisure activities, education and work.

Career guidance is coordinated function aimed at assisting the referral entity to enhance competitiveness in labor market and having coordinated continuous progress through ongoing self development and self improvement during whole working activity.

Professional orientation or career guidance

As already mentioned career guidance is a lifelong service and is not just about work after the learning process, but these two are interrelated. 'The term career guidance is replacing the term vocational guidance in high-income countries, vocational guidance is focused upon the choice of occupation and is distinguished from educational guidance, which focuses upon choices of study courses. Career guidance brings the two together and stresses the interaction between learning and work (Hansen 2006: 1). The most comprehensive and widely accepted definition of Career guidance is provided by OECD (2004). Career guidance is commonly understood as set of services in this document refers to services and activities intended to assist people of any age and at any point throughout their lives to make educational, training and occupational choices and to manage their careers. Career guidance helps people to reflect on their ambitions, interests, qualifications and abilities. It helps them to understand the labor market and educational systems, and to relate this to what they know about themselves. Comprehensive career guidance tries to teach people to plan and make decisions about work and learning. Career guidance makes information on the labor market and educational opportunities more accessible by organizing, systematizing and making it available when and where people need it. (OECD 2004: 10)

In other words, the career guidance is an inclusive term that has been used to describe a range of activities that help people to move from a general understanding of life and work to a specific understanding of life, learning and working realistic options. 


\section{REFERENCES}

1. The Organisation for Economic Co-operation and Development (OECD), Career Guidance - A Handbook for Policy Makers. 2004

2. European Centre for the Development of Vocational Training [CEDEFOP], Benchmarking tool for Quality Assurance in Vocational Education and Training. 2004

3. Development of Professional Orientation System in the Republic of Armenia, The Concept addopted by the Government of RA, N 40, 04.10.2012

4. Кононогова О. И. “Профессиональное самоопределение учащихся в учереждениях дополнительного образования", “Педагогика”, 2007.

5. Пряжников Н. С. , Профориентация в школе и колледже - игры, упражнения, опросники. 8-11 классы, ПТУ и колледж. Москва, ВАКО, 2008.

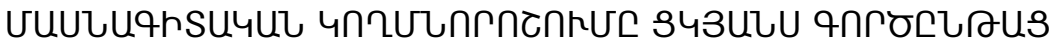

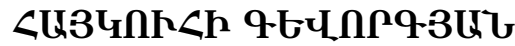

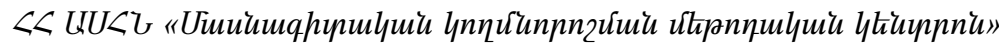

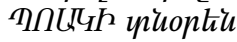

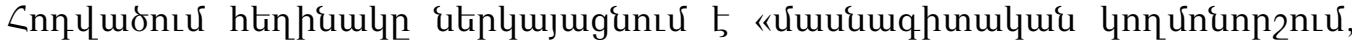

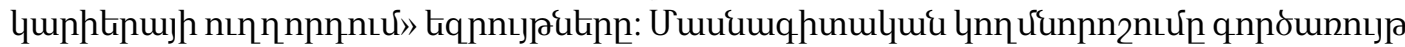

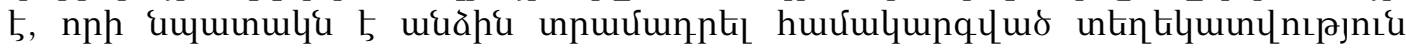

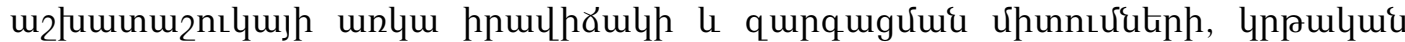

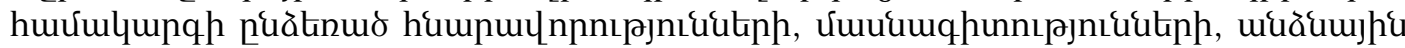

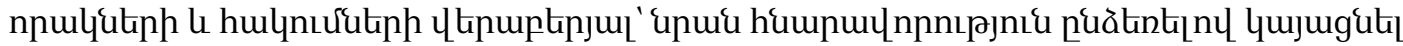
qhunulggluo le unnjnıtumut tiun nnn2nıu:

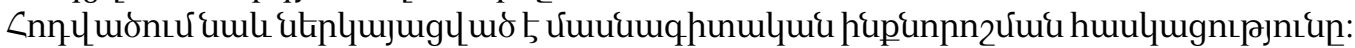

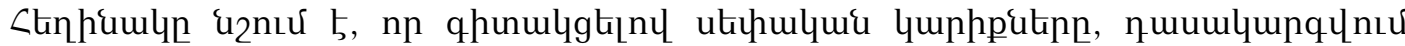

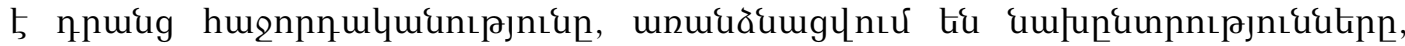

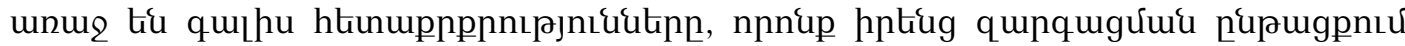

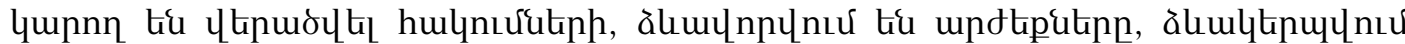

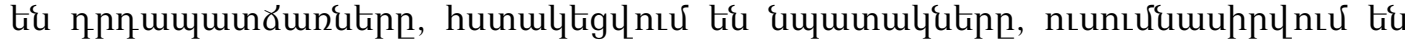

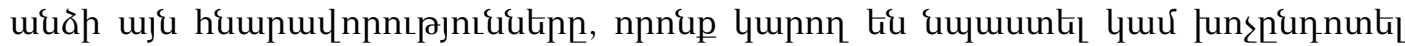

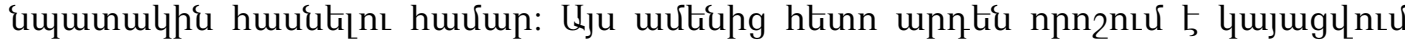

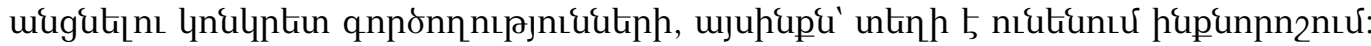

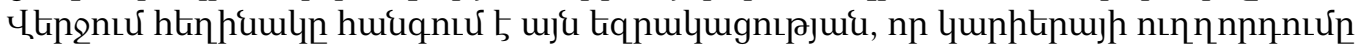

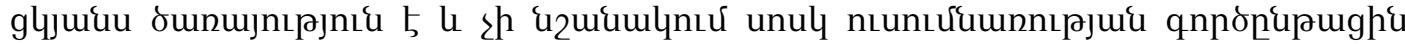

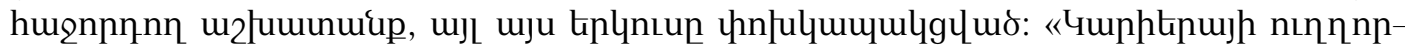

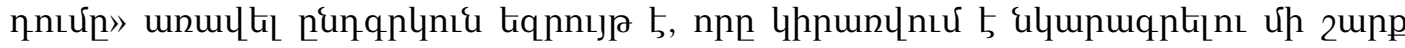

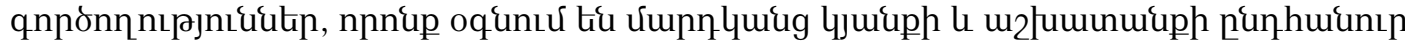

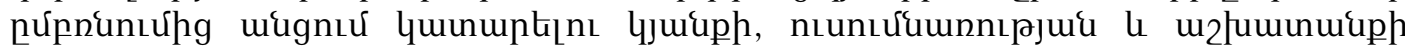

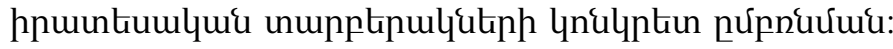




\section{ПРОФВЕССИОНАЛЬНАЯ ОРИЕНТАЦИЯ КАК НЕПРЕРЫВНЫЙ ПРОЦЕСС ГЕВОРКЯН АЙКУИ}

Директор ГНКО «Методический иентр профессиональной ориентации» Министерства труда и социальных вопросов РА

В статье автор представляет термины «профессиональная ориентация/направление карьеры». Целью профессиональной ориентации является предоставление систематизированной информации о текущем состоянии и возможных путях развития рынка труда, возможностях, предоставляемых системой образования, специальностях, личностных качествах и стремлениях, помогая индивидууму принять осознанное и эффективное решение.

Также в статье приводится понятие профессионального самоопределения. Автор отмечает, что осознание и систематизация собственных потребностей позволяют определить предпочтения, на первый план выходят интересы, которые в своем развитии могут перейти в предрасположенности, формируются ценности, исследуются те возможности личности, которые могут способствовать или мешать достижению цели. После всего этого принимается решение о переходе к конкретным действиям, то есть имеет место самоопределение.

В заключение автор приходит к выводу, что профессиональная ориентация - это непрерывный процесс и не является исключительно работой, следующей за исследованием, эти два явления взаимосвязаны. «Направление карьеры» - это всеобъемлющее явление, которое применяется при описании ряда действий, позволяющих людям перейти от общего понимания жизни и работы к точному пониманию реальных вариантов жизни, учебы и работы. 